\title{
The influence of Macroeconomic Indicators and Foreign Ownership on Government Bond Yields: A Case of Indonesia
}

\author{
Augustina Kurniasih \\ Yulia Restika \\ Postgraduate Program, Mercu Buana University \\ augustina.kurniasih@gmail.com and yulia_restika@yahoo.com
}

\section{Doi:10.5901/mjss.2015.v6n5s5p34}

\section{Abstract}

The purpose of this research is to examine and analyze the influence of inflation, $B I$ rate, exchange rate, and foreign ownership on government bond yields. Research data is monthly data from 2010 to 2013. Purposive sampling is chosen as the sampling method in this research. Based on the determined criteria, 23 government bonds have fulfilled the sample criteria. The result of this research shows that inflation, $B I$ rate, exchange rate, and foreign ownership simultaneously have a significant influence on government bond yields. Partially, inflation and BI rate have positive significant influence on government bond yield, while exchange rate and foreign ownership have negative significant influence on government bond yield.

Keywords: Inflation, BI Rate, Exchange Rate, Foreign Ownership, Government Bond Yields

\section{Introduction}

Bond market is one of the financing source alternatives, both for the government and the corporations (Fabella and Madhur, 2003). Closing the government deficit budget through the domestic loan is considered necessary for Indonesian government (Sihombing et al, 2012). The government conducts domestic financing through the issuance of government bonds or known as Government Securities. By issuing bonds, the government takes part in establishing and developing bond market in Indonesia (Sihombing et al, 2012).

Government Debt Securities is one of Government Securities that is unconditionally issued by the government and considered as an instrument of portfolio investment for domestic and foreign investors. Government Debt Securities is one type of Government Bond with the largest value issued by Indonesian government for the national development purposes.

One of the benchmarks used by investors to monitor the development of government bond market is through observing the bond yields. The yield is considered as a reference of yield expectation or as a performance measurement of their bonds portfolio (Sihombing et al, 2013). In the last few years the high bond yields produce powerful yields (Lindquist and Cimarosa, 2014). However, the bond yields happen to face volatility from time to time, as represented in Figure-1 (the yield development of one of Government Bond sample series, namely FR0028).

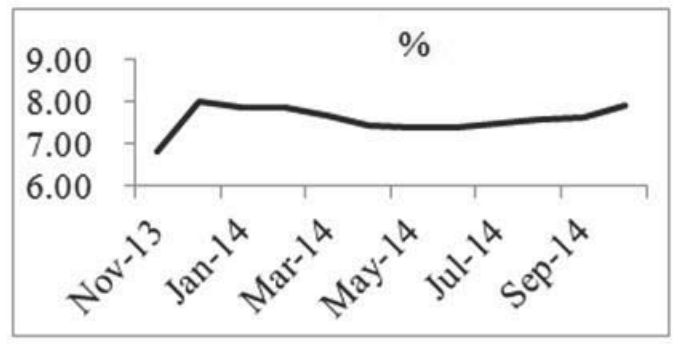

Figure 1. Monthly Government Bond Yield Series FR0028 (IBPA, 2014) 
Figure 1 shows the graphic of government bond yields series FR0028 in the beginning of the month, started from November 2013 to October 2014. The graphic indicates sharp increase of yield in November 2013. Considering the importance of yields for Government Bond investors, they need to monitor the increase or decrease of yields from time to time.

The investors of Bond Government are not only from local investors but from foreign investors as well. Figure 2 describes the percentage of foreign ownership on the Government Securities which tends to grow. The increasing of foreign ownership percentage proves that investors have high interest on Government Securities.

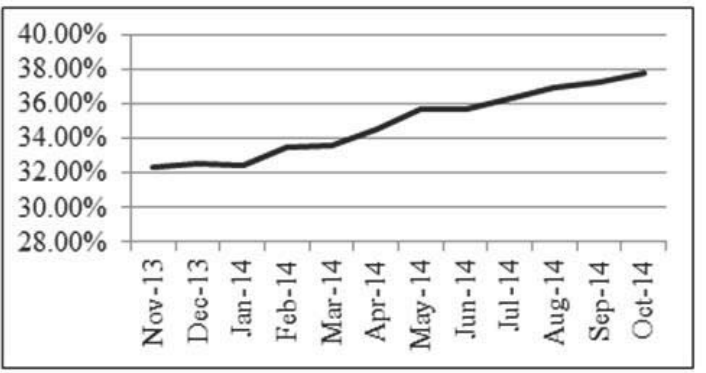

Figure 2. Foreign Ownership on Government Securities (DJPU, 2014)

The investment value and result are vary due to the change of interest rate, exchange rate or other factors (Leibowitz and Bova, 2014). Bond is sensitive to inflation rate, interest rate, as well as exchange rate (BEI, 2014).

Bond yields contain premium risk as a compensation to uncertain inflation (Azoulay et al, 2007). All existing interest rates, including deposit and bond yield, will refer to $\mathrm{BI}$ rate with adjustment to the due date (Bank Indonesia, 2013). Research conducted by Sianipar (2011) shows that inflation has a positive influence, while BI rate has a negative influence on Government Bond yield. On the contrary, the result of research conducted by Rahman and Sam'ani (2013) indicates a positive influence between inflation and Government Bond yield, while BI rate has no significant influence at all. Meanwhile, Poghosyan (2012) concludes in the research regarding short term and long term determinants towards goverment bond yield in advanced economy shows that the short term bond yield is positively influenced by the real money market price and negatively influenced by inflation.

Based on the explanation as above, below are the questions research 1) Does inflation influence Government Bond yield? 2) Does BI Rate influence Government Bond yield? 3) Does exchange rate influence Government Bond yield? 4) Does foreign ownership influence Government Bond yield?

\section{Literature Review}

Government Bond. In accordance with Law No. 24 Year 2002, Government Bond is a type of Government Debt Securities which has more than 12 months period with coupon and/or with discounted interest payment. Government Bond with coupon is Government Debt Securities in which the interest payment is calculated by certain percentage of nominal value and paid regularly. In addition, Government Bond with discounted interest payment is Government Debt Securities with more than 12 months period and its interest payment is implicitly reflected in the difference of issuance price and nominal value obtained in the maturity period.

In Indonesia the government issues Government Bond in Rupiah and foreign currency. Based on the type of coupon, Government Bond is divided into Government Bond with fixed rate and Government Bond with variable rate. Fixed Rate Bond is classified into Regular Fixed Rate, Zero Coupon, and Indonesian Retail Government Bond (ORI).

The interest payment in Fixed Rate (FR) is conducted regularly per semester, while in Variable Rate (VR) is per quarter. Furthermore, the interest payment in ORI is regularly paid per month. The interest payment of FR Regular bond is fixed until the maturity period. Zero Coupon Bond does not pay coupon, but receive a specific amount at maturity period (Directorate of Government Debt Securities, 2011)

Government Bond Coupon. Government Bond, except Zero Coupon, offers benefits which is interests or coupon. Coupon is the amount of interest paid regularly which is stated in the percentage on bond nominal value (Directorate of Government Debt Securities, 2011). 
Government Bond Yield. Yield is the earnings level required by market for bonds (Ross et al, 2009). There are two types of yield: current yield (simple yield) and yield to maturity (Directorate of Government Debt Securities, 2011). Current yield is measured by dividing the level of bond coupon with bond acquisition (buying) price (Directorate of Government Debt Securities, 2011). Current yield is greater than coupon if the bond buying price is lower than nominal value, and vice versa (Čerović et.al, 2014). Yield to maturity is the earnings level that represents the benefits of bond investment with the higher accuracy level compared to the current yield (Directorate of Government Debt Securities, 2011). Yield to maturity is single discount rate. Once it is implemented in the payment, all coupons in the future and all basic values will generate the present value which is equal to the buying price (Forbes et al, 2008). The term yield to maturity is generally known as yield. Another interpretation of yield is price of money (Directorate of Government Debt Securities, 2011).

Price, or bond price, theoretically is the present value from all cash incomes in the future, either coupon or basic value in maturity, by using certain interest level as its discount rate. Such interest level is called yield to maturity (YTM) (Directorate of Government Debt Securities, 2011). Following is the formula of bond price (Bodie et al, 2011):

Price $=\sum_{t=1}^{T} \frac{\text { Coupon }}{(1+r)^{t}}+\frac{\text { Par value }}{(1+r)^{T}}$

Where:

Price $=$ bond price

Coupon $=$ bond coupon

$r=$ yield to maturity

$T=$ time

Par value $=$ bond value on maturity

There is a negative or reserve correlation between bond price and yield (Bodie et al, 2011). When yield increases, the price will decrease, ceteris paribus (Directorate of Government Debt Securities, 2011).

The yield condition is in volatility. Yield volatility is the compensation of risk credit, market volatility, and liquidity scarcity (Haan et al, 2013).

Foreign Ownership in Government Securities. Indonesian economic development requires a significant amount of funds. Domestic funding sources apparently are insufficient to support the national economic development to the bigger scale. Therefore, foreign investments are considered necessary to assist domestic investments. Nowadays, foreign investors provide a significant amount of funds to invest in the developing countries, including Indonesia. However, they will tend to seek countries with high attractiveness, such as adequate infrastructure, conducive investment environment, security and political stability, macroeconomics stability, as well as law enforcement (Sihombing, 2013).

Foreign investors may act as catalyst in the local bond market development, particularly by carrying out basic diversification of institutional investors and establishing greater demand of bonds for developing countries market. Domestic institutional investors are generally those who buy and hold bonds to maturity, while foreign investors tend to buy and sell their bonds. Therefore, they give more contribution to make the market liquid. The increasing foreign ownership may result greater volatility in bond market (Peiris, 2010).

The participation of foreign investors in government bond in the developing market by using local currency may influence the yield level and volatility of bonds. Developing market is able to attract numerous foreign investors' funds to government bonds with local currency and lower yield, but apparently, it is more susceptible to market sentiment (Ebeke and Lu, 2014).

Foreign investment in Government Securities in the capital market may become as an alternative to fund the national economic development. In addition, the rise of foreign ownership indicates a positive signal because it is one of the indicators to measure investors' trust on Government Securities. Such thing can also portray the credibility of Indonesian capital market from foreign investors' point of view. The greater meaning from the increase of foreign ownership in Government Securities indicates the high trust from foreign investors on national economic development process (Sihombing, 2013).

Macroeconomic Indicators. Inflation. Inflation is the increasing of prices in general. Inflation is a continuing process of increasing of prices, not the high increase of prices. Therefore, the high price level does not necessarily show inflation. It will be considered as inflation if the price continues to increase and influences each other (Sukanto, 2009).

It is generally known that inflation may have a bad influence to the economic growth. Thus, inflation is an indicator to show economic instability in a country (Antoni, 2010). If the inflation continues to rise, the purchasing power will decline, then the bond liquidity is influenced and the price decreases (Sukanto, 2009). Such thing is in line with Blose (2010) which elaborated Fisher Hypothesis (1896) in which the higher inflation will result the fixed income investment less attractive and will impact on the decreasing price. Bond is one of the investments with the fixed income.

As the compensation of inflation instability, bond yield contains premium risk. Countries with stable inflation may 
have less premium risk in determining bond price (Azoulay et al, 2007).

BI Rate (Central Bank rate). Bond investors consider the amount of interest rate as the main consideration of the expected return level. Baldacci and Kumar (2010), cited Elmendorf and Mankiw's explanation (1998) that refers to the standard of Neoclassical Model, stated that fiscal deficit (ceteris paribus) will reduce the national savings and increase aggregate demands. This creates government's excessive debt which then causes an increase in the interest rate. An excessive debt makes the obligation price decreases. This explanation is inline with Caron and Spaltro (2014) who explained that the decreasing interest trend might not look attractive to investors with fixed income (including obligation) to get an attractive return. The rise of interest rate gives an enormous impact on yield (Mouchakkaa, 2014). Moreover, the interest rate may change according to the entire economic conditions (Siahaan, 2008). Therefore, if the interest rate increases, the bond yield will also increase but the bond price will decrease. In Indonesia, BI rate is commonly used as the benchmark for general interest rate.

Exchange Rate. Exchange rate is the price for which the currency of a country can be exchanged for another country's currency. The stability of rupiah exchange rate is crucial for national economic because it is closely related to the economic growth in Indonesia. The most essential thing in the exchange rate of rupiah is its volatility itself since it may impact the financing, including bond (Rambe, 2012).

In general, countries with high inflation rate tend to have weak currency value. However, there are some exceptions, such as the inflation occurred in 1980s in United States. Compared to the inflation in Japan, the inflation in US is increasing more quickly but in the same time US dollar is appreciated against Japanese yen. In this case, there are other factors which negatively influence against the inflation and compensating the other factor.

Some prior researches regarding yield bond have been conducted. Sianipar (2011) conducted research related to influence of inflation, exchange rate of Rupiah, $\mathrm{BI}$ rate and foreign ownership in the domestic bond on yield of maturity. The data is analyzed using regression method. The research result shows that inflation and exchange rate have negative impact on bond yield to maturity, while BI rate and foreign ownership have positive impact on bond yield to maturity.

Rahman and Sam'ani (2013) analyzed several factors that influence Government Bond yield in 2010 - 2012. The research result shows that bond maturity and inflation have positive influence on bond yield, while BI rate did not have significant influence. In addition, currency and oil price have a negative influence on bond yield.

Ichsan et al (2013) examined the impact of BI rate, interest rate, exchange rate, and inflation on government bond value. The research shows that such components have a significant influence on government bond value.

\section{Hypothesis}

The increase of inflation rate tends to cause the decrease of bond price. It reflects the inflation increment tends to cause bond yield increasing as bond price is inversely influence to bond yield (Moss and Houle, 2010).

$\mathrm{H}_{1}$ : Inflation has a positive influence on Government Bond yield

All existing interest rates, including deposit interest and bond yield, will refer to $\mathrm{BI}$ rate with the adjustment on the maturity (Bank Indonesia, 2013).

$\mathrm{H}_{2}$ : BI rate has a positive influence on Government Bond yield

Bonds are sensitive to inflation rate, interest rate, as well as exchange rate (Indonesia Stock Exchange, 2014). The result of researches conducted by Hsing (2010) as well as Rahman and Sam'ani (2013) show that exchange rate has a negative influence on bond yield.

$\mathrm{H}_{3}$ : Exchange rate has a negative influence on Government Bond yield.

The rise of foreign ownership indicates a positive signal because it is one of the indicators to measure investors' trust on Government Securities (Sihombing, 2013:195). The increase of foreign ownership in Government Securities indicates the high trust from foreign investors on national economic development process and it may reduce Government Bond yield as a part of Government Securities (Sihombing, 2013).

$\mathrm{H}_{4}$ : Foreign ownership has a negative influence on Government Bond yield.

\section{Method}

This research design is causality study. This design is choose because this research wants to find that a change in one variable (independent variable) cause some predictable change in another variable (dependent variable) (Cooper and Schindler, 2002).

There is one dependent variable in this research and four independent variables. Table 1 presents the operational definition and the measurement of each variable. 
Table 1. Operational Definition and Variable Measurement

\begin{tabular}{|c|c|c|c|}
\hline Variable & Operational Definition & Measurement & Source \\
\hline $\begin{array}{l}\text { Government Bond } \\
\text { Yield }\end{array}$ & Government Bond Yield To Maturity & $\begin{array}{l}\text { Government Bond yield in the beginning of } \\
\text { the month }\end{array}$ & www.ibpa.co.id \\
\hline Inflation & Monthly inflation (year on year) & Inflation rate in year t-1 & www.bi.go.id \\
\hline Interest Rate & Monthly interest rate & $\mathrm{BI}$ rate at the end of the month in year $\mathrm{t}-1$ & www.bi.go.id \\
\hline Exchange Rate & $\begin{array}{l}\text { Exchange rate of rupiah per US dollar at } \\
\text { the beginning of the month }\end{array}$ & $\begin{array}{l}\text { Exchange Rate (Average) }= \\
\frac{\text { Buy Rate+Sell Rate }}{2}\end{array}$ & www.bi.go.id \\
\hline Foreign Ownership & $\begin{array}{l}\text { Total foreign ownership bond on } \\
\text { Government Securities traded at the } \\
\text { beginning of the month (rupiah } \\
\text { denomination) }\end{array}$ & $\begin{array}{l}\text { Percentage of foreign ownership on } \\
\text { Government Securities }\end{array}$ & www.djpu.kemenkeu.go.id \\
\hline
\end{tabular}

The research population is all Government bonds listed in Indonesia Stock Exchange from 2010 to 2013 (100 bonds in total). The sample is obtained by using non-probability technique and determining certain criteria, as follows: 1) included as Government Bond series Fixed Rate - Regular with Rupiah denomination, and 2) actively traded in Indonesia Stock Exchange (have been traded in 30 days/month). There are 23 bonds that fulfill the requirements for sample criterion.

The research data are ratio data which are monthly data within the period $2010-2013$. The research data are panel data which means the combination of cross section data and time series. In general, there are three popular panel models, namely pooled regression, fixed-effect model, and random effect model (Rosadi, 2012).

To choose the best panel model, the following tests are conducted: 1) Restricted F Test, to determine or to choose either pooled regression model or random effect model; 2) Hausman Test, to choose either fixed effect model or random effect model; 3) Breusch-Pagan Test or Lagrange Multiplier Test, to choose either pooled regression model or random effect model (Gujarati, 2008).

Multiple linear regression approach is carried out to test the research hypothesis. Following is the equation of multiple linear regressions in this research:

$$
\begin{aligned}
& Y_{i t}=\beta_{0}+\beta_{1} X_{1 i(t-1)}+\beta_{2} X_{2 i(t-1)}+\beta_{3} X_{3 i t}+\beta_{4} X_{4 i t}+\varepsilon_{i t} \\
& \text { Where: } \\
& Y_{i t}=\text { government bond Yield series-i at time-t } \\
& X_{1 i(t-1)}=\text { Inflasion series-i at time-t } \\
& X_{2 i(t-1)}=\text { interest rate series-i at time-t } \\
& X_{3 i t}=\text { exchange rate series-i at time-t } \\
& X_{4 i t}=\text { foreign ownership series-i time-t } \\
& \beta_{0}=\text { constant } \\
& \beta_{1}, \beta_{2}, \beta_{3}, \beta_{4}=\text { regression coefficient } \\
& \varepsilon_{i t}=\text { error term }
\end{aligned}
$$

\section{Result And Discussion}

The descriptive statistics of research variable are presented in Table-2. Total observation for each variable is 1.104 data (samples are 23 series of Government Bond in 2010 - 2013, monthly data).

Table 2. Descriptive Statistic of Research Variables

\begin{tabular}{lccc}
\hline Variables & Minimum Value & Maximum Value & Mean Value \\
\hline Yield & 4,04 & 10,83 & 7,21 \\
Inflation & 2,78 & 8,79 & 5,32 \\
BI Rate & 5,75 & 7,50 & 6,31 \\
Exchange Rate & $8.481,00$ & $11.946,00$ & $9.395,46$ \\
Foreign Ownership & 18,54 & 35,52 & 29,81 \\
\hline
\end{tabular}

The average of Government Bond monthly yield in 2010 - 2013 was 7,21\%. The minimum value of yield was 4,04\%, obtained from Government Bond yield series FR0051 on May 2013, while the maximum value was 10,83\%, obtained 
from Government Bond yield series FR0050 on January 2010. From the maturity of Government Bond, it shows that the minimum value of yield occurs in FR0051 which has the shortest tenor. On the contrary, the maximum value of yield occurs in FR0050 which has the longest tenor.

The average of monthly inflation in 2010 - 2013 was 5,32\%. The lowest inflation was $2,78 \%$ which was during year on year inflation on December 2009. It has become the lowest inflation since 1999. Meanwhile, the highest inflation was $8,79 \%$ which occurred on August 2013. This inflation occurs due to the increase of electricity price on July 2013 and Ramadhan period.

The average of $\mathrm{BI}$ rate in 2010 - 2013 was $6,31 \%$. The lowest rate was 5,75\% which happened from February 2012 until May 2013, while the highest rate was 7,5\% which occurred on November 2013. Bank of Indonesia continue to maintain BI rate in level 5,75\% from February 2012 until May 2013. In 2013, Bank of Indonesia increased BI rate and it reached 7,5\% in November 2013.

The average of monthly exchange rate for Rupiah in 2010 - 2013 was $9.395,46$. The lowest exchange rate was 8.481 that occurred in August 2011 and the highest exchange rate was 11.946 that happened in December 2013. The high exchange rate of Rupiah, which started to increase on June 2013, was reasonable. Such thing also took place in numerous emerging market countries (not only in Indonesia), due to the policy of US Federal Reserve to withdraw monetary stimulus fund which cost around US\$ 85 billion per month for bond buying. The main consideration of this action is the US economic conditions which continue to recover.

The average of foreign ownership on Government Securities per month in $2010-2013$ was 29,81\%. The lowest foreign ownership was $18,54 \%$ on January 2010 . On the other hand, the highest foreign ownership was $35,52 \%$ on August 2011. Foreign ownership on Government Securities continues to rise since January 2010 to August 2011.

Table 3 shows the result of Restricted $F$ test. The value of $F$ test or Chi-square has $p$-value $=0,00$ (less than $5 \%$ ), so $\mathrm{H}_{0}$ is rejected. It means pooled regression model is not suitable for this research. Therefore, Hausman test should be conducted.

Table 3. Restricted F-test

\begin{tabular}{lccc}
\hline Restricted $\boldsymbol{F}$ & Statistic & d.f. & Probability \\
\hline Cross-section F & 131,12 & $(22,1077)$ & 0,00 \\
Cross-section Chi-square & $1.437,96$ & 22 & 0,00 \\
\hline
\end{tabular}

The result of Hausman test (Table-4) indicates that the probability value of cross section random effect test is 1,00 or the probability level is $100 \%$ ( $p$-value $>0,05$ ), so $\mathrm{H}_{0}$ is accepted. Thus, random effect is considered as the best model and Breusch-Pagan test is unnecessary.

Table 4. Hausman Test

\begin{tabular}{lccc}
\hline Uji Hausman & Chi-Sq. Statistic & Chi-Sq. d.f. & Probabilitas \\
\hline Cross-section random & 0,00 & 4 & 1,00 \\
\hline
\end{tabular}

The test result of dependent variable influence on bond yield is presented in Table-5. The coefficient of determination worth $91,6079 \%$ and it indicates the ability of independent variables (inflation, BI rate, exchange rate, as well as foreign ownership) to predict dependent variable variety (Government Bond yield) is $91,6079 \%$. The rest $8,3921 \%$ is described by other independent variables not mentioned in this research. Random effect model is relevant because F-count valued 2.999; significant at $\alpha=1 \%$.

Following is the equation for multiple linear regression in this research, in accordance with Table- 5 . 
Table 5. The Result of Estimated Coefficient of the Influence of Inflation, BI Rates, Exchange Rate, and Foreign Ownership on Government Bond Yield in Indonesia

\begin{tabular}{|c|c|c|c|c|c|}
\hline & Variable & Coefficient & $T_{\text {value }}$ & Sign & \\
\hline & Constant & 7,926053 & 22,34154 & 0,0000 & $* * *$ \\
\hline & Inflation & 0,293362 & 20,52572 & 0,0000 & $* * *$ \\
\hline & BI Rate & 1,610351 & 46,25642 & 0,0000 & $* * *$ \\
\hline & Exchange Rate & $-0,000493$ & $-24,31030$ & 0,0000 & $* * *$ \\
\hline & Foreign ownership & $-0,262052$ & $-66,30412$ & 0,0000 & $* * *$ \\
\hline & $\mathbf{R}^{2}$ & 0,916079 & & & \\
\hline & $F_{\text {value }}$ & & 2999,175 & 0,0000 & *** \\
\hline \multicolumn{6}{|c|}{$\begin{array}{l}\text { Notes: } \\
\star \star * \text { significant at } \alpha=1 \%\end{array}$} \\
\hline \multicolumn{6}{|c|}{$\begin{array}{l}\left.Y_{t}=7,926053+0,293362 X_{1(t-1)}+1,610351 X_{2(t-1)}-0,000493 X_{3 t}-0,262052 X_{4 t} \ldots \ldots \ldots . .3\right) \\
\text { where: }\end{array}$} \\
\hline \multicolumn{6}{|c|}{$Y_{t} \quad=$ Government bond Yield at $\mathrm{t}$} \\
\hline \multicolumn{6}{|c|}{$X_{1(t-1)}=$ Inflasion on $\mathrm{t}-1$} \\
\hline \multicolumn{6}{|c|}{$X_{2(t-1)}=\mathrm{BI}$ Rate on $\mathrm{t}-1$} \\
\hline$X_{3 t}$ & $=$ exchange rate at time-t & & & & \\
\hline$X_{4 t}$ & $=$ foreign ownership at time-t & & & & \\
\hline
\end{tabular}

The constant value is $7,926 \%$ and significant. It means if all independent variables are zero, the government bond yield worth 7,926\%. This value is much smaller compared to yield constant value in 2013 from research carried out but Rahman and Sam'ani (2013) which was $93,291 \%$. On the other hand, compared to the average of deposit interest in 2014 which valued 7,75\% (The rate of Indonesia Deposit Insurance Corporation for Commercial Banks) Government Bond yield is much higher.

The coefficient of inflation variable regression is 0,293362 , significant at $\alpha=1 \%$. There is a positive correlation between inflation and Government Bond yield. If the inflation rises 1\%, the Government Bond yield will increase $0,293362 \%$.

The coefficient of $\mathrm{BI}$ rate is 1,610351 , significant at $\mathrm{a}=1 \%$. Its correlation with Government Bond yield is positive, so when there is a $1 \%$ increment on $\mathrm{BI}$ rate, the Government Bond yield will increase $1,610351 \%$.

The coefficient of exchange rate is $-0,000493$ and significant at $\alpha=1 \%$. The correlation between exchange rate and Government Bond yield is negative, which means the Government Bond yield will decrease 0,000493\% in every 1 Rupiah increment of exchange rate.

Finally, the coefficient of foreign ownership is $-0,262052$ and significant at $\alpha=1 \%$. It indicates the negative correlation between foreign ownership and Government Bond yield. Thus, the $1 \%$ increase of foreign ownership equals to $0,262052 \%$ decrease in Government Bond yield.

\section{Discussion}

Inflation Influence. Result of this research shows that inflation has a positive influence on Government Bond yield. This result supports Fisher Hypothesis. It supports the hypothesis $\mathrm{H}_{1}$ as well as the opinion of Moss and Houle (2010) which stated that the rise of inflation rate tends to cause the fall of bond price. It means the increasing inflation is equal to the rise of bond yield because bond price has inverse effect to bond yield. The result also supports the research conducted by Rahman and Sam'ani (2013) that showed a positive influence between inflation and Government Bond yield. This study also support the research result of Ang and Piazzesi (2003) which found that inflation has a positive influence on Government Bond yield in Poland.

However, this research result is the opposite of the research carried out by Sianipar (2011) which showed that inflation has a negative influence on bond yield to maturity in Indonesia. The finding is also did not support the result of Poghosyan (2012) who concluded that inflation has a negative influence on short term bond yield in 22 countries with advanced economy in 1980-2010 period.

The Influence of BI Rate. BI rate has a positive influence on Government Bond yield. This research result supports the statement from Bank of Indonesia (2013) that bond yield refers to BI rate so the increase of BI rate will be followed by the rise of Government Bond yield. In addition, this research result is also in line with Ebeke and Lu (2014) which elaborated that interest rate has a positive influence on bond yield in developing countries. Another research conducted 
by Moss and Houle (2010) which stated that the interest rate might cause the decrease of bond price is also supported by this research result. It implies that the interest rate increment tends to make bond yield increase because the bond price is a reserved to bond yield.

The finding of this research is also in line with Barr and Campbell (1996) who described that the change of interest and inflation has negative correlation in a short term but not in a long one. The same thing is also said by Poghosyan (2012) stated that the interest rate has a positive influence on short term bond yield in 22 countries in advanced economy. Nevertheless, the result of this research is contradictory with Rahman and Sam'ani's (2013) which mentioned that $\mathrm{BI}$ rate did not have significant influence on bond yield in Indonesia.

The Influence of Exchange Rate. This research result shows that exchange rate has a negative influence on Government Bond yield. Such finding supports the research result conducted by Sianipar (2011) which concluded that exchange rate has a negative influence on bond yield. In addition, the research conducted by Hsing also found that there is a negative influence between exchange rate and Government Bond yield in Poland. On the other hand, the result is quite different with the research carried by Ebeke and Lu (2014) which reveals that exchange rate has a positive influence on bond yield in developing countries.

The Influence of Foreign Ownership. Foreign ownership has a negative influence on Government Bond yield. The result of this research is in line with Sihombing (2013) which explained that the greater meaning from the increase of foreign ownership in Government Securities indicates the high trust from foreign investors on national economic development process, and it may reduce Government Bond yield as a part of Government Securities. The increase of foreign ownership indicates the decrease of investment risk in Indonesia. Risk is parallel with return. If the return decreases, it means the bond yield will also decreases. This research result is in line with the findings of Peiris (2010) which concluded that the high foreign participation or foreign ownership in the bond market in developing countries tends to reduce Government Bond yield significantly. Moreover, Ebeke and Lu (2014) elaborated that the high foreign ownership may result the low bond yield. However, this research result is the opposite of Sianipar's (2011) which showed that foreign ownership has a positive influence on yield of maturity of 31 Fixed Rate domestic bonds issued by the government and listed in Indonesia Stock Exchange within July 2009 until December 2010.

\section{Conclusion and Suggestion}

Some conclusions of this research are 1) Inflation has a positive influence on Government Bond yield. Therefore, the higher the inflation, the higher the Government Bond yield; 2) BI rate has a positive influence on Government Bond yield. When $\mathrm{BI}$ rate is high, Government Bond yield will also be high; 3) Exchange rate has a negative influence on Government Bond yield. When the exchange rate USD on Rupiah is high, then the Government Bond yield will be low; and 4) Foreignownership has a negative influence on Government Bond yield. Thus, the higher the foreign ownership, the lower the Government Bond yields will be.

$\mathrm{BI}$ rate shows the greatest influence among all dependent variables in this research. Therefore, investors who expect to obtain the satisfying return from their investment in government bond need to pay attention to $\mathrm{BI}$ rate. It is suggested that the next researcher may examine the fundamental factors, including time period, coupon, and modified duration, of Government Bond as the variable that influences its yield. It is therefore expected to obtain better results as the factors that influence Government Bond yield.

\section{References}

Ang, Andrew dan Monika Piazzesi. 2003. "A No-Arbitrage Vector Autoregression of Term Structure Dynamics with Macroeconomic and Latent Variables". Journal of Monetary Economics, 50, 745-787.

Antoni. 2010. "Kointegrasi Antara Inflasi dan Pertumbuhan Ekonomi di Indonesia". Jurnal Ekonomi, Bisnis dan Koperasi. Vol.12, No.2, Oktober 2010, 1-11.

Azoulay, Eddy, Menachem Brenner, dan Yoram Landskroner. 2007. "Inflation Expectations Derived From Foreign Exchange Options". Journal of Economic Literature.

Bank Indonesia. 2013. Gerai Info. Jakarta.

Baldacci, Emanuele anda Manmohan S. Kumar. 2010. "Fiscal Deficit, Public Debt, and Sovereign Bond Yields". IMF Working Paper WP/10/184. Fiscal Affairs Department. International Monetary Fund.

Barr, David G. and John Y. Campbell. 1996. "Inflation, Real Interest Rates, and the Bond Market: A Study of UK Nominal and IndexedLinked Government Bond Prices". Working Paper 5821. National Bureau of Economic Research. Cambridge

Blose, Laurence E. 2010. "Gold Prices, Cost of Carry, and Expected Inflation". Journal of Economics and Business 62. 35-47

Bodie, Zvi, Alex Kane, and Alan J. Marcus. 2011. Investments. 9th edition. McGraw-Hill//rwin. New York. 
Bursa Efek Indonesia. 2014. IDX Newsletter. Jakarta.

Caron, Jim and Marco Spaltro. 2014. "Climate Change for Bonds". Investment Management Journal. Vol.4, Issue.2, 69-80.

Čerović, Slobodan, Marina Pepić, Stanislav Čerović, dan Nevena Čerović. 2014. "Duration and Convexity of Bonds". Singidunum Journal of Applied Sciences. 11(1), 53-66.

Cooper, Donald R. and Pamela S.Schindler. 2011. Business Research Method 11edition. McGraw Hill//rwin. New York.

Direktorat Surat Utang Negara. 2011. Istilah Umum Terkait dengan Investasi pada Surat Utang Negara. Kemenkeu. Jakarta.

Ebeke, Christian and Yinqiu Lu. 2014. "Emerging Market Local Currency Bond Yields and Foreign Holdings in the Post-Lehman Period-a Fortune or Misfortune?". IMF Working Paper. European Department.

Fabella, Raul dan Srinivasa Madhur. 2003. "Bond Market Development In East Asia: Issues And Challenges". Economics And Research Department. Asian Development Bank.

Fisher, Irving. 1896. Appreciation and Interest. Publication of the American Economics Association. 1-98

Forbes, Shawn M., John J. Hatem, dan Chris Paul. 2008. "Yield-to-Maturity and the Reinvestment of Coupon Payments". Journal of Economics and Finance Education. Vol.7, No.1, 48-51.

Ghozali, Imam. 2013. Aplikasi Analisis Multivariate dengan Program IBM SPSS 21. Edisi 7. Badan Penerbit Universitas Diponegoro. Semarang.

Gujarati, Damodar N. and Dawn C. Porter. 2011. Basic Econometrics. 5th edition. McGraw-Hill//rwin. New York.

Haan, Leo de, Jeroen Hessel, and Jan Willem van den End. 2013. "Are European Sovereign Bonds Fairly Priced? The Role of Modeling Uncertainty". DNB Working Paper. No. 399, November 2013.

Hsing, Yu. 2010. "Government Debt and the Long-Term Interest Rate: Application of an Extended Open-Economy Loanable Funds Model to Poland". Journal of Economic Literature.

Ichsan, Ghazali Syamni, Nurlela, dan A. Rahman. 2013. "Dampak Bi Rate, Tingkat Suku Bunga, Nilai Tukar, dan Inflasi Terhadap Nilai Obligasi Pemerintah". Jurnal Keuangan dan Perbankan. Vol.17, No.2, Mei 2013, 310-322.

Leibowitz, Martin and Anthony Bova. 2014. "Portfolio Strategy: Rolling Yields and Return Convergence". Investment Management Journal. Vol.4, Issue.2, 19-33.

Lindquist, Richard and Jack Cimarosa. 2014. "The Case for Middle Market High Yield Investing". Investment Management Journal. Vol.4, Issue.2, 8-17.

Mouchakkaa, Paul. 2014. "Frozen on the Rates: Impact of Interest Rates on Capitalization Rates". Investment Management Journal. Vol.4, Issue.2, 3-7.

Moss, William D. dan Lori Booth-Houle. 2010. "Bonds, Interest Rates, and the Impact of Inflation". Moss Booth Wealth Advisors. Scottsdale.

Peiris, Shanaka J. 2010. "Foreign Participation in Emerging Markets' Local Currency Bond Markets". IMF Working Paper. Monetary and Capital Markets Department.

Poghosyan, Tigran. 2012. "Long-run and Short-run Determinants of Sovereign Bond Yield in Advanced Economy". IMF Working Paper. WP/12/271. International Monetary Fund.

Rahman, Anang Aulia dan Sam'ani. 2013. "Analisis Faktor-Faktor yang Mempengaruhi Yield Obligasi Negara Tahun 2010 - 2012". Jurnal Ekonomi - Manajemen - Akuntansi No. 35.

Rambe, M.K. Aswan. "Analisis Faktor-Faktor Ekonomi yang Mempengaruhi Penerbitan Obligasi Negara". Tesis Pascasarjana. IPB. Bogor.

Republik Indonesia. 2002. "Undang-Undang No. 24 Tahun 2002 tentang Surat Utang Negara". Lembaran Negara RI. No. 110. Sekretariat Negara. Jakarta.

Rosadi, Dedi. 2012. Ekonometrika \& Analisis Runtun Waktu Terapan dengan Eviews. Andi. Yogyakarta.

Ross, Stepehen; Westerfield, Randolph; and Jordan, Bradford D.. 2009. Fundamentals of Corporate Finance 9th ed. McGraw Hill. Irwin. New York

Siahaan, Edward S. 2008. "Analisis Faktor-Faktor Yang Berpengaruh Terhadap Perubahan Harga Obligasi". Tesis. Universitas Diponegoro. Semarang.

Sianipar, Aryanti Sariartha. 2011. "Pengaruh Inflasi, Nilai Tukar Rupiah, Tingkat Suku Bunga BI, dan Kepemilikan Asing dalam Obligasi Domestik terhadap Yield To Maturity". Skripsi. Universitas Padjajaran. Bandung.

Sihombing, Jonker. 2013. Investasi Asing Melalui Surat Utang Negara di Pasar Modal. P.T. Alumni. Bandung.

Sihombing, Pardomuan, Hermanto S, Adler HM dan Perdana WS. 2012. "Analisis Pengaruh Makro Ekonomi Terhadap Term Structure Interest Rate Obligasi Pemerintah (SUN) Indonesia". Journal of Capital Market and Banking. Vol. 1, No. 2, Agustus 2012, $103-$ 114.

Banking Journal. Vol. 15, No. 1, Juni 2013, 68-89.

2013. "Determinan Yield Curve Surat Utang Negara". Finance and

Sukanto, Eman. 2009. "Pengaruh Suku Bunga Deposito, Kurs Rupiah-USD, Tingkat Inflasi, IHSG dan Volume Transaksi Terhadap Harga Obligasi Pemerintah RI (SUN)". Jurnal Fokus Ekonomi. Vol.4, No.2, Desember 2009, 9-23. 